University of Nebraska - Lincoln

DigitalCommons@University of Nebraska - Lincoln

Textile Society of America Symposium

Proceedings

$10-2020$

\title{
An Uncommon Ammunition Case: Interpreting "Transitional" Textiles and Social Worlds in Nineteenth-Century Tlingit Alaska
}

Laura J. Allen

Independent Scholar and Curatorial Specialist, laura@laura-allen.com

Follow this and additional works at: https://digitalcommons.unl.edu/tsaconf

Digitart of the Art and Materials Conservation Commons, Art Practice Commons, Fashion Design Commens, Fiber, Textile, and Weaving Arts Commons, Fine Arts Commons, and the Museum Studies Netwarkns

Logo

Allen, Laura J., "An Uncommon Ammunition Case: Interpreting "Transitional" Textiles and Social Worlds in Nineteenth-Century Tlingit Alaska" (2020). Textile Society of America Symposium Proceedings. 1164. https://digitalcommons.unl.edu/tsaconf/1164

This Article is brought to you for free and open access by the Textile Society of America at DigitalCommons@University of Nebraska - Lincoln. It has been accepted for inclusion in Textile Society of America Symposium Proceedings by an authorized administrator of DigitalCommons@University of Nebraska - Lincoln. 


\title{
An Uncommon Ammunition Case: Interpreting "Transitional" Textiles and Social Worlds in Nineteenth-Century Tlingit Alaska
}

\author{
Laura J. Allen \\ laura@laura-allen.com
}

An unassuming case for ammunition, often overlooked in the vast Tlingit collection at the American Museum of Natural History (AMNH) in New York, bears an unusual combination of woven designs. The weaver likely hailed from the Jilkaat Tlingit village of Klukwan in southeast Alaska, where Lieutenant George Thornton Emmons obtained this bag in the mid-1880s. At that time, Klukwan was renowned for hand-twined robes (naaxein) and other textiles that Indigenous women made from cedar bark and mountain-goat wool in the "Chilkat" style, which was named after this place. On the case's flap, the weaver followed the curvilinear conventions of Chilkat design to create a figure with two piercing eyes-likely a crest that identifies the owner's lineage.

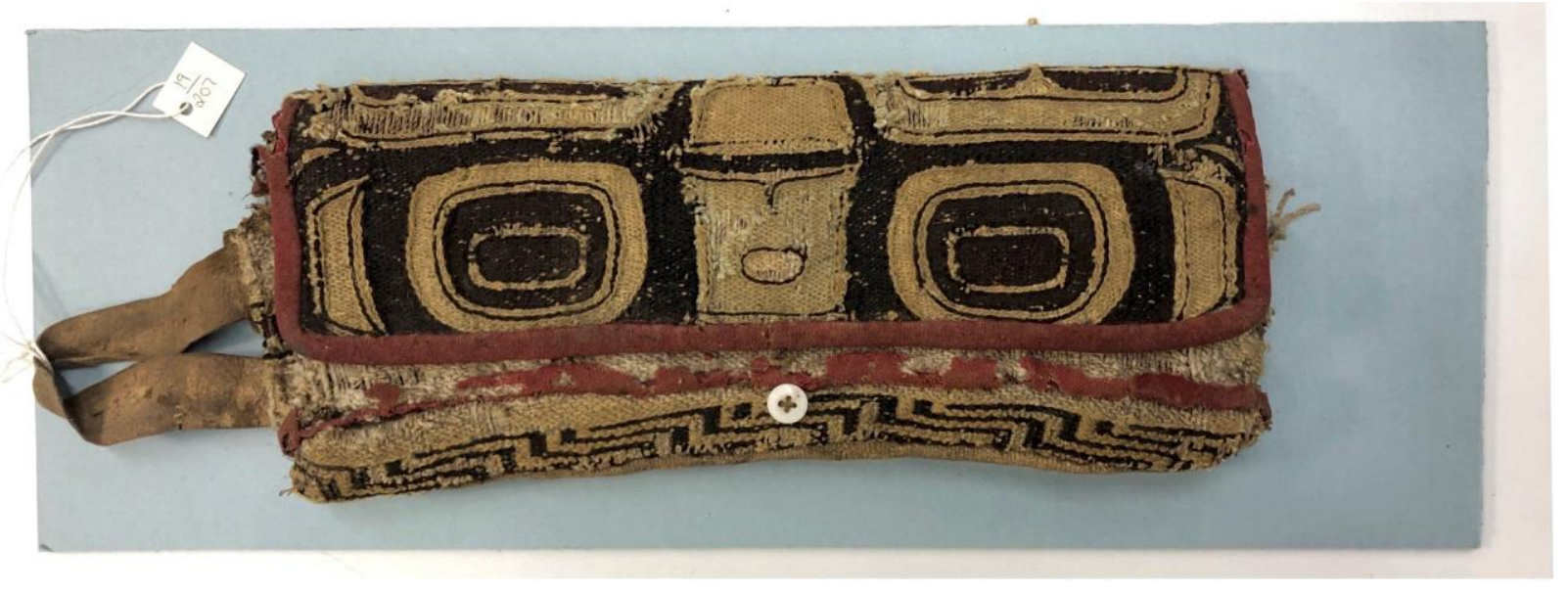

Ammunition case (front), artist once known, Chilkat Tlingit. Collected 1882-1887. Cedar bark, mountain-goat wool, metal, trade cloth, hide, glass. $11 \times 4$ 3/4 in. Image: Laura Allen; Courtesy of the Division of Anthropology, American Museum of Natural History, 19/207.

For the main body of the case, the weaver carefully planned geometric designs in a two-color stair-step pattern, which are more easily visible in the image on the next page. The geometric designs are reminiscent of one of the precursor styles to Chilkat weaving, Yéil Koowú (Raven's Tail) or northern geometric weaving. Weavers stopped producing Raven's Tail in the early-tomid 1800s until reviving it in the 1980s. ${ }^{1}$ Unlike Chilkat weavings, Raven's Tail weavings are usually rendered exclusively in wool, with no cedar bark, and are technically and visually more closely related to local spruce-root basketry. ${ }^{2}$

\footnotetext{
${ }^{1}$ Cheryl Samuel, The Raven's Tail (Vancouver, BC: UBC Press, 1987), 160; Steve Henrikson, “Yéil Koowú: The Reemergence of Ravenstail Weaving On the Northwest Coast," American Indian Art Magazine 18, no. 1 (Winter 1992): 59.

${ }^{2}$ Mary Lois Kissell, "The Early Geometric Patterned Chilkat,” American Anthropologist 30, no. 1 (1928): 116; Samuel, Raven's Tail, 26.
} 


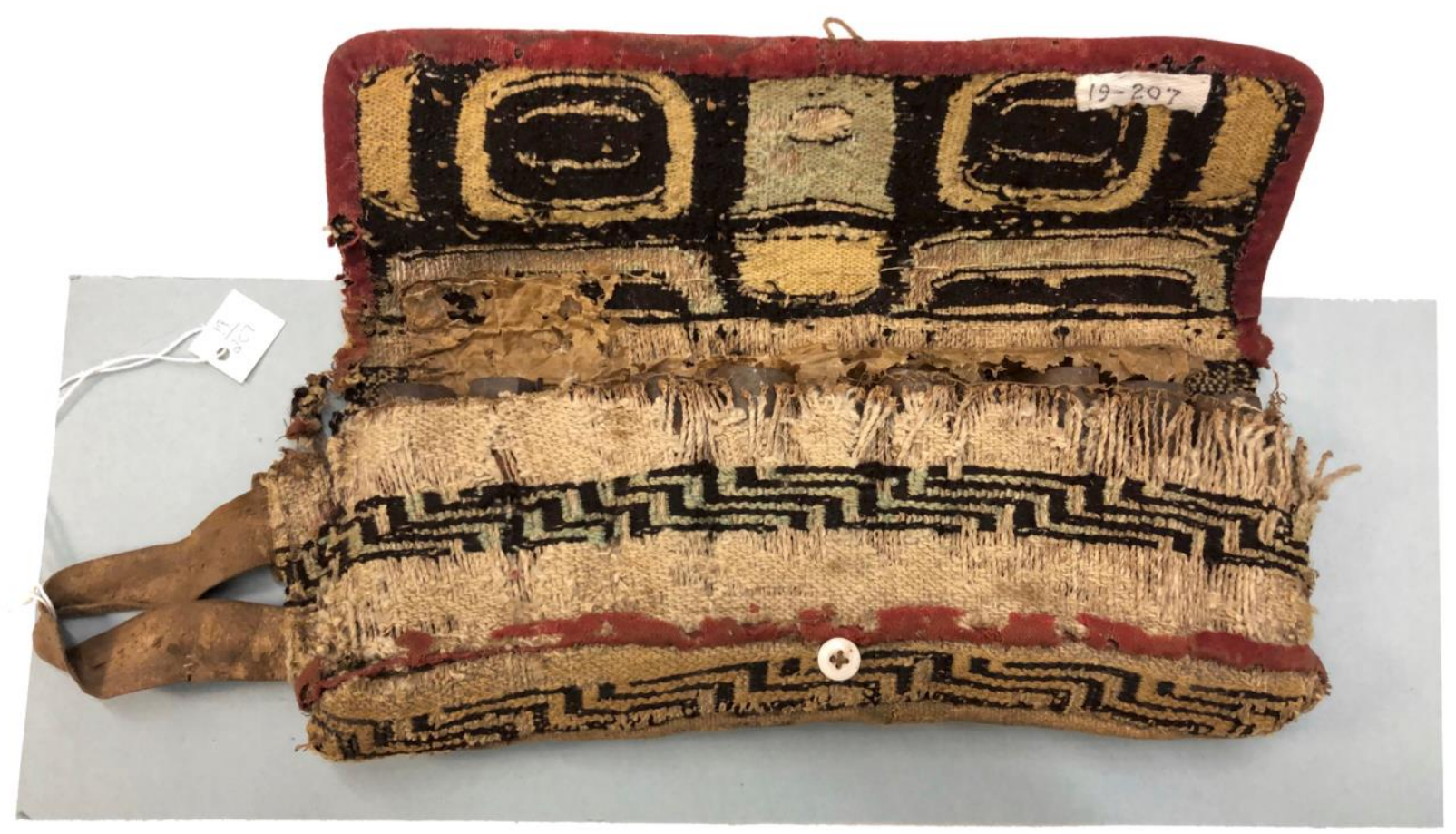

Ammunition case (open), artist once known, Chilkat Tlingit. Collected 1882-1887. Cedar bark, mountain-goat wool, metal, trade cloth, hide, glass. $11 \times 4$ 3/4 in. Image: Laura Allen; Courtesy of the Division of Anthropology,

American Museum of Natural History, 19/207.

Scholars have identified a small number of historic weavings in museum collections that appear stylistically "between" the two techniques of Raven's Tail and Chilkat; these items show both geometric and curvilinear elements. So-called "transitional" pieces are usually dated to the late eighteenth and early nineteenth centuries, when geometric weaving was waning and figural designs were gaining in popularity. Scholars generally interpret "transitional" pieces as evidence of a linear shift from one dominant style to another. ${ }^{3}$

I began this study curious whether this ammunition case-which has been published on very little — was by this definition a "transitional" weaving. ${ }^{4}$ While numerous people have reviewed this special object in AMNH storage over the decades, its relative obscurity aligns with the general scholarly neglect of small weavings from the Northwest Coast compared to the attention devoted to the large Chilkat robe. As scholar Aaron Glass writes in the catalog for Objects of

\footnotetext{
${ }^{3}$ For example, see Samuel, Raven's Tail, 130-160; Bill Holm, “A Wooling Mantle Neatly Wrought: the Early Historic Record of Northwest Coast Pattern-Twined Textiles," American Indian Art Magazine 8, no. 1 (Winter 1982): 34-47; and George Thornton Emmons, The Tlingit Indians, edited with additions by Frederica de Laguna and a biography by Jean Low, Anthropological Papers of the American Museum of Natural History 70 (Seattle: University of Washington Press, 1991), 228-233.

${ }^{4}$ Images and short descriptions of the woven case appear in Rebecca Klassen, "Ammunition Case," in Objects of Exchange: Social and Material Transformation on the Late Nineteenth-Century Northwest Coast, ed. Aaron Glass (New York: Bard Graduate Center, 2011), 133 and in Katie Pasco, "The Tsimshian Connection in Weaving the Painted Formline," American Indian Art Magazine 22, no. 2 (1997): 45. See also "Beau Dick (Kwakwakąwakw) on Ammunition Cases," Objects of Exchange, Bard Graduate Center, accessed January 30, 2021, https://www.bgc.bard.edu/objects-exchange-beau-dick.
} 
Exchange, a 2011 exhibit of nineteenth-century material culture from the Northwest Coast, "What is frequently lost in the standard taxonomic project [is the] boundary object....the apparently unclassifiable." 5

As I researched the visual, historical, and cultural significances of this pouch, it soon became clear that this object does not represent a stylistic and technical evolution from geometric to figural. Instead, I suggest that this case's use, construction, and motifs attest to major artistic and social transitions - as well as continuities - occurring within Tlingit communities during the nineteenth century. Among other aspects, the pouch illuminates issues of gender in textile design, shifts in symbolism for regalia, and adaptations in the look and socioeconomic roles of dress, textiles, and basketry.

In this paper, I contextualize the ammunition case's attributes using comparative objects, ethnohistorical sources, and dialogues with individuals from the Northwest Coast. In assessing this object and its social worlds, I benefit from, while also critiquing, some of Franz Boas' approaches to art history. In particular, I find valuable his emphasis on multiple, ambiguous interpretations of both form and content, and his interests in resisting straightforward narratives about stylistic change. ${ }^{6}$ At the same time, I attempt to redress biases that he and his peers set in motion about "women's art" of the Northwest Coast. ${ }^{7}$ I also draw from more contemporary anthropological work that recognizes the shifting meanings of material culture relative to its historical and sociocultural contexts, particularly colonial conditions. ${ }^{8}$

Instead of "transitional," I interpret this outlier weaving as a connective object in the social lives of the mid- to late-nineteenth century Tlingit. I argue that this object links changing modes of expression and social relations during a period of intense colonial pressure, a turbulent time through which Tlingit communities and their textiles adapted and endured.

\section{$\underline{\text { Uses }}$}

Tlingit speakers call this type of object an at káté daakéit or "bullet container." The owner of the woven case would have worn it dangling from his waist belt using the leather strap. ${ }^{10}$ Tacked inside the woven case are 11 metal cylinders designed to hold ammunition cartridges,

\footnotetext{
${ }^{5}$ Glass, Objects of Exchange, 7.

${ }^{6}$ Aldona Jonaitis, introduction to A Wealth of Thought: Franz Boas on Native American Art (Seattle: University of Washington Press, 1995), 3-37.

${ }^{7}$ Aldona Jonaitis, "The Scientist and the Polymath: Tlingit Weavers Teri Rofkar and Clarissa Rizal," in Hearts of Our People: Native Women Artists, ed. Jill Ahlberg Yohe and Teri Greeves (Minneapolis: Minneapolis Institute of Art, 2019), 124.

${ }^{8}$ Nicholas Thomas, Entangled Objects: Exchange, Material Culture, and Colonialism in the Pacific (Cambridge, MA: Harvard University Press, 1991); Glass, Objects of Exchange.

9 Translation by David Katzeek, email to Garfield George, May 25, 2020. Unless otherwise noted, for Tlingit terms I use the orthography of X'unei Lance Twitchell, ed., Tlingit Dictionary (Juneau: University of Alaska Southeast/Goldbelt Heritage Foundation, 2016).

${ }^{10}$ See Frederica de Laguna, Under Mount Saint Elias: The History and Culture of the Yakutat Tlingit, Smithsonian Contributions to Anthropology, vol 7 (Washington: Smithsonian Institution Press, 1972), 426.
} 
individually prepared paper packets containing a projectile and gunpowder to insert into the muzzle of a musket. ${ }^{11}$ Tlingit people first obtained firearms from maritime fur traders around 1790 and used old-style muzzleloaders for most of the nineteenth century. ${ }^{12}$

Along with the widespread use of firearms, fashionable Tlingit clan leaders also adopted Russian- and American-style military garments and accessories - as well as Tlingit-made pieces designed after them - for formal wear during the fur-trade period. Elites appropriated Western power dressing to declare wealth and status, signaling their high-level dealings with military officers and commercial traders. ${ }^{13}$ In kind, Tlingit makers sometimes crafted at káté daakéit from prefabricated colonial wooden cartridge boxes for use during hunting or warfare, often customizing them with crests (see the central object in the image on the following page). ${ }^{14}$ The hand-woven case is similar in shape and style to the wooden case depicted, yet it is uncommon to find ammunition cases that are made from prestigious, ceremonial Chilkat fabric. The woven case also has some utilitarian touches: for example, it is lined with waterproof gutskin, which likely protected the contents and the weaving in rough conditions. ${ }^{15}$

In the decades after the Russian sale of Alaska to the United States in 1867, Tlingit people stopped conducting warfare. ${ }^{16}$ By the late nineteenth century, artists were making beaded ammunition cases out of trade cloth (see the red object on the next page). These beaded cases, which often have long ties for the wearer to cinch around their waist, were designed for more ornamental use at ku.éex', or local potlatches. Some have parallel stitching that only simulates cartridge slots. ${ }^{17}$

\footnotetext{
11 "Manuscript Catalog," Collections Database, E/2278, AMNH Division of Anthropology, https://anthro.amnh.org/objectlist.html?object_list=+++E\%2F+2278; Accession File, 16/9520, AMNH Division of Anthropology Archives. Steve Henrikson notes that the Tlingit may not have actually used prefabricated cartridges with their guns, so pouches like this one would not have been very convenient to carry firearm-related items (email to author, September 30, 2020).

${ }^{12}$ Emmons, Tlingit Indians, 130; see also John R. Swanton, "Contributions to the Ethnology of the Haida," in Memoirs of the American Museum of Natural History, vol. 8, part 1 (New York: American Museum of Natural History, 1905): 106, http://digitallibrary.amnh.org/handle/2246/5742; and de Laguna, Under Mount Saint Elias, 187, 589.

${ }^{13}$ A. V. Grinëv, The Tlingit Indians in Russian America, 1741-1867, trans. Richard L. Bland and Katerina G. Solovjova (Lincoln: University of Nebraska Press, 2005), 231-232; https://search-ebscohostcom.ezproxy.cul.columbia.edu/login.aspx?direct=true \&db=e025xna\&AN=135774; Steve Henrikson, email message to author, September 30, 2020.

${ }^{14}$ Klassen, "Ammunition Case”; Henrikson, email message to author, September 30, 2020.

${ }^{15}$ Lani Hotch, interview by author, April 28, 2020; see also de Laguna, Under Mount Saint Elias, 425.

${ }^{16}$ See for example Sergei Kan, "Events and Nonevents on the Tlingit/Russian/American Colonial Frontier, 18021879," in New Perspectives on Native North America: Cultures, Histories, and Representations, ed. Sergei Kan, Pauline Turner Strong, and Raymond Fogelson (Lincoln: University of Nebraska Press, 2006), 313-16, 321-22; Emmons, Tlingit Indians, 358.

${ }^{17}$ Megan Smetzer, email message to author, July 9, 2020.
} 

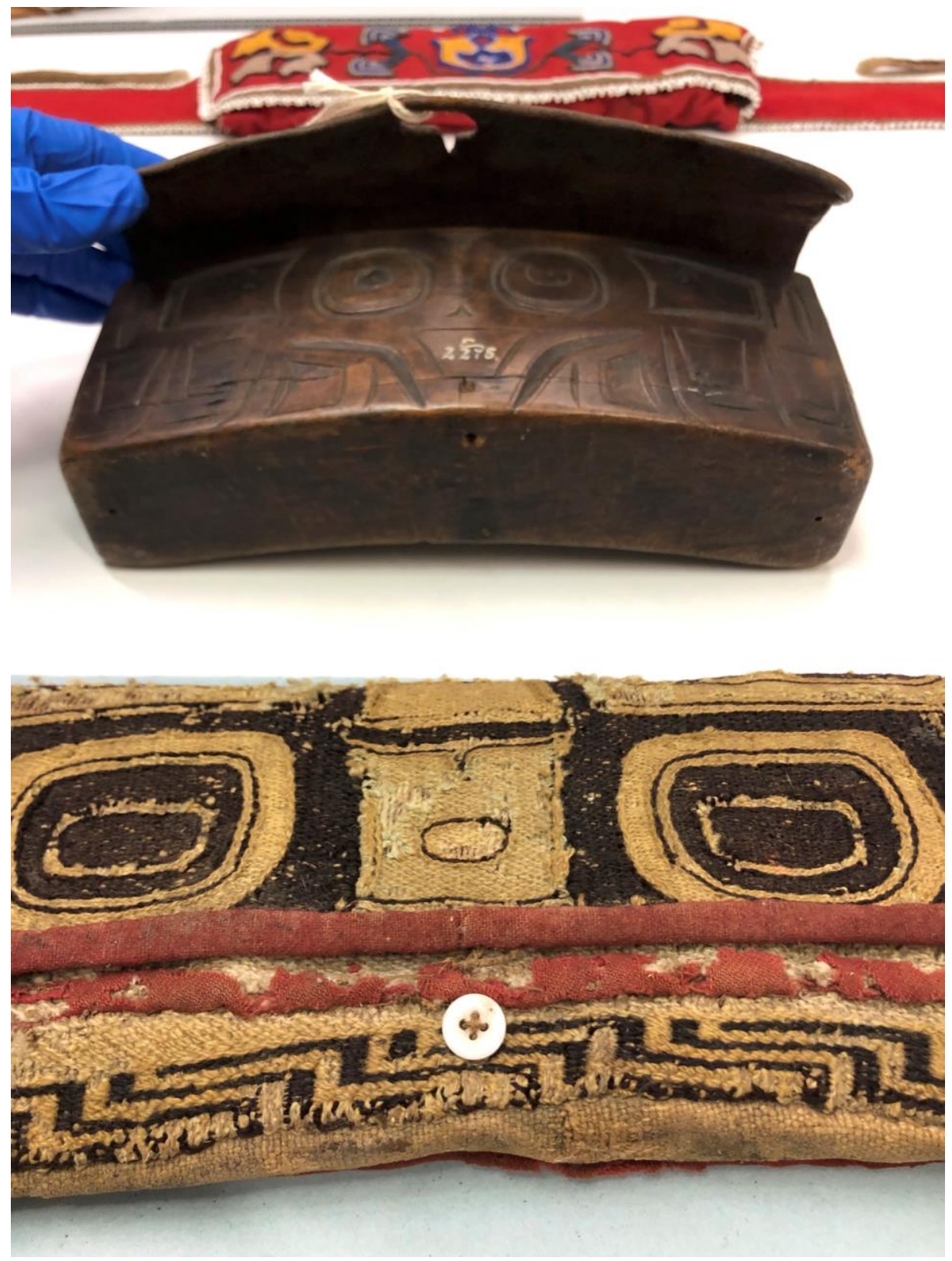

(T) Cartridge belt, artist once known, Tahltan. Accessioned 1904. Wool and cotton cloth, glass beads, metal. $33.5 \times 4$ in. AMNH 16/9520. (C) Ammunition case, artist once known, Hoonah Tlingit. Accessioned 1894. Wood, hide, metal. 8 3/4 $x 4$ in. AMNH

E/2278. (B) Ammunition case, artist once known, Chilkat Tlingit. Collected 1882-1887. Cedar bark, mountain-goat wool, metal, trade cloth, hide, glass. $11 \times 4$ 3/4 in. 19/207. Image: Laura Allen; Courtesy of the Division of Anthropology, American Museum of Natural History.

In the image on the next page, the man in the front row at left wears a large beaded case at his waist. Art historian Megan Smetzer suggests that beaded cartridge belts and ammunition cases in the late nineteenth and early twentieth centuries were only used in a symbolic fashion as visual 
metaphors of the Tlingit's "powerful militaristic past": important social messaging of resistance in a colonial climate increasingly disruptive to Indigenous lifeways. ${ }^{18}$

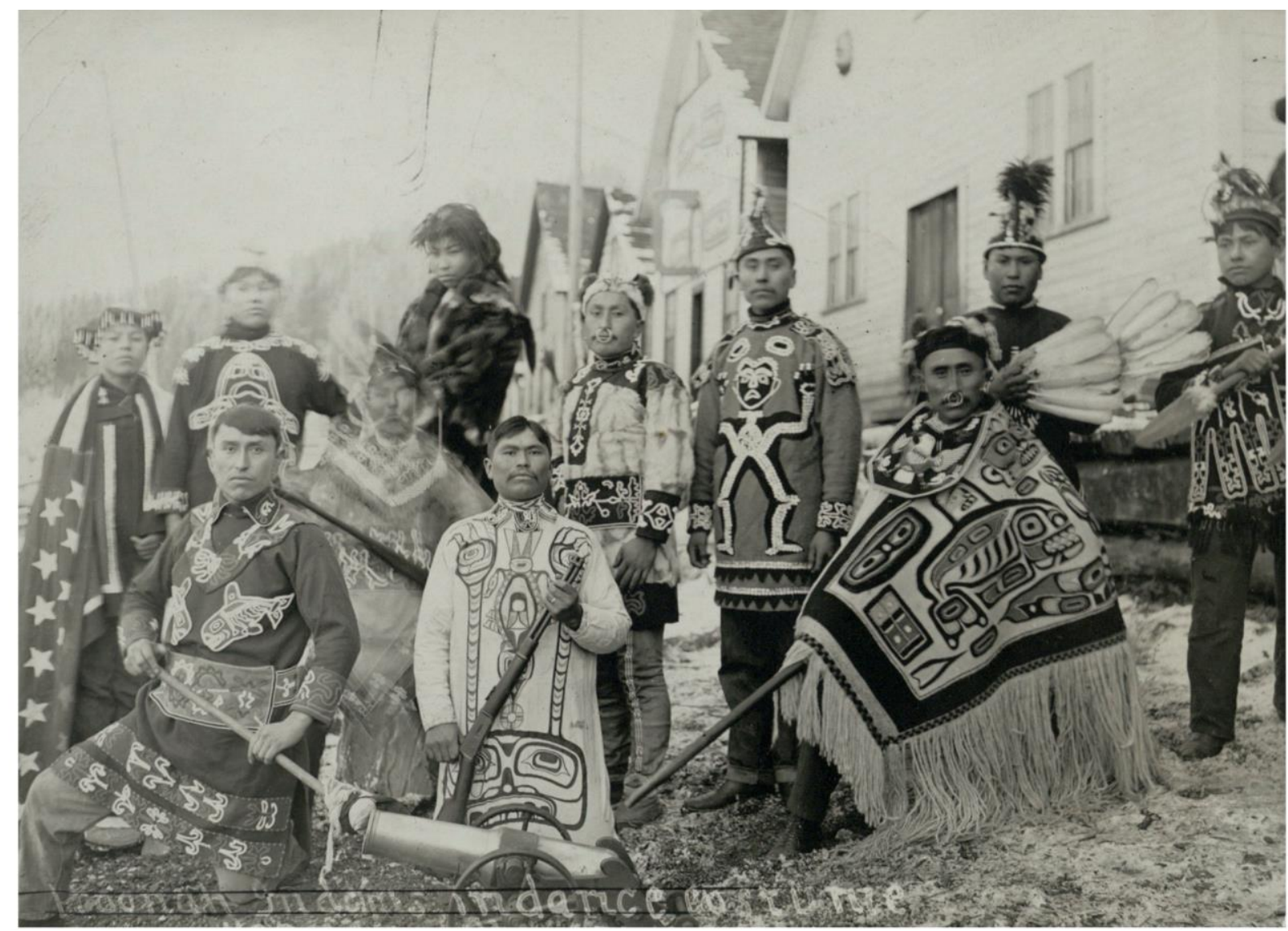

Hoonah Tlingit people pose in potlatch dress, 1890-1910. The man kneeling on the left wears a beaded cartridge belt around his waist. Note the display of a gun and cannon as further militaristic metaphors. Alaska State Library, Clarence Leroy Andrews Photo Collection, C. L. Andrews, P45-1281.

In my view, the woven Jilkaat ammunition case occupies an ambiguous space between a more utilitarian purpose - to keep ammunition at the ready — and an exclusively ceremonial one, to display social power in potlatching. Lani Hotch, a fourth-generation weaver from Klukwan and the Executive Director of the Jilkaat Kwaan Heritage Center, proposes that the case's owner could have worn it for long-distance trade transactions in which ceremony and the display of status were critical. ${ }^{19}$ "Especially when newly made, it would have been quite impressive to wear

\footnotetext{
${ }^{18}$ Megan Smetzer, "Assimilation or Resistance? The Production and Consumption of Tlingit Beadwork" (PhD diss., Vancouver, University of British Columbia, 2007), 131.

${ }^{19}$ For descriptions of Chilkat trade see Emmons, Tlingit Indians, 56-57. Hotch suggests that the case's extreme wear patterns could have resulted from swinging against the wearer's legs while walking over the Chilkat Trail and/or from it being in a grave site (interview by author, April 28, 2020). I also considered the latter, as Emmons sometimes searched shamans' graves to obtain objects to sell to museums. However, Emmons usually indicated on his records when he did so for a particular piece. While the wear is suspect, I have not yet found direct evidence that Emmons took this case from a grave.
} 
over the [Chilkat] trail and do some trade with our interior partners," she said. ${ }^{20}$ Whether the case was used for war, trade, and/or ceremony, the chiefly fabric would have afforded the wearer prestige and authority when negotiating interpersonal power relations.

\section{$\underline{\text { Construction and Motifs }}$}

I turn now to the case's patterning, both its overall shape and motifs. My research suggests that its construction and iconography exemplify women's ongoing roles as textile designers in the nineteenth century as well as the shifting social meanings of conventionalized geometric designs. In these ways, the case further serves as a "connective object."

All of the pouch's warps are made from cedar bark hand-spun with mountain-goat wool, and all of the wefts are mountain-goat wool alone - the standard materials of historical Chilkat weaving. The textile card in AMNH's catalog records notes that the case is "made of scraps of Chilkat blankets patched together." ${ }^{11}$ This comment refers to the fact that women on the Northwest Coast sometimes created ceremonial apparel using cut-up pieces of Chilkat robes that their families had received as potlatch gifts. ${ }^{22}$ However, my research suggests that this case was not patchworked from a larger object or objects. Numerous people I spoke with suggested that the maker intentionally wove a single piece of fabric to create this specific case.

While the bag does have some seams, an important juncture-where the geometrically woven back transitions to the figural flap - is not seamed. (See image on the next page.) Instead, it has continuous warps that form the base for all of the twining, whether geometric or figural. The case's deliberate design is also evident in the flap, whose dimensions conform to the being that is depicted. ${ }^{23}$ Haida weaver Evelyn Vanderhoop, who has studied this piece at AMNH more than once, told me that "the design is in proportion to the object," suggesting that the maker planned and wove the ammunition case as a single unit, then cut it into its pattern pieces. ${ }^{24}$

The maker's intentionality has several implications. Cheryl Samuel, in her seminal 1982 book The Chilkat Dancing Blanket, wrote that purpose-woven small Chilkat objects such as leggings, headpieces, and pouches "were probably individual expressions of the combined imaginations of artist and weaver, to be duplicated in spirit but not in kind." ${ }^{25}$ In this statement, Samuel emphasizes that the artist - meaning the person who designed the motifs - and the weaver were different people. This is because for historical Chilkat weavings, men typically painted the curvilinear designs on a wooden pattern board for female weavers to follow as a template.

\footnotetext{
${ }^{20}$ Hotch, interview by author, April 28, 2020.

21 “Textile Card," Collections Database, 19/207, AMNH Division of Anthropology, https://anthro.amnh.org/objectlist.html?object_list=19++\%2F++207

${ }^{22}$ Emmons, Tlingit Indians, 228. This “destruction” of chiefly textiles actually adds value to the resulting patchwork regalia, as it signals that the robe owner has so much property that it can be divided and shared (Evelyn Vanderhoop, email to author, August 28, 2019).

${ }^{23}$ Vanderhoop, email message to author March 2, 2020; Lily Hope, interview by author, April 23, 2020.

${ }^{24}$ Vanderhoop, email message to author, March 3, 2020.

${ }^{25}$ Cheryl Samuel, The Chilkat Dancing Blanket (Norman: University of Oklahoma Press, 1982), 27.
} 


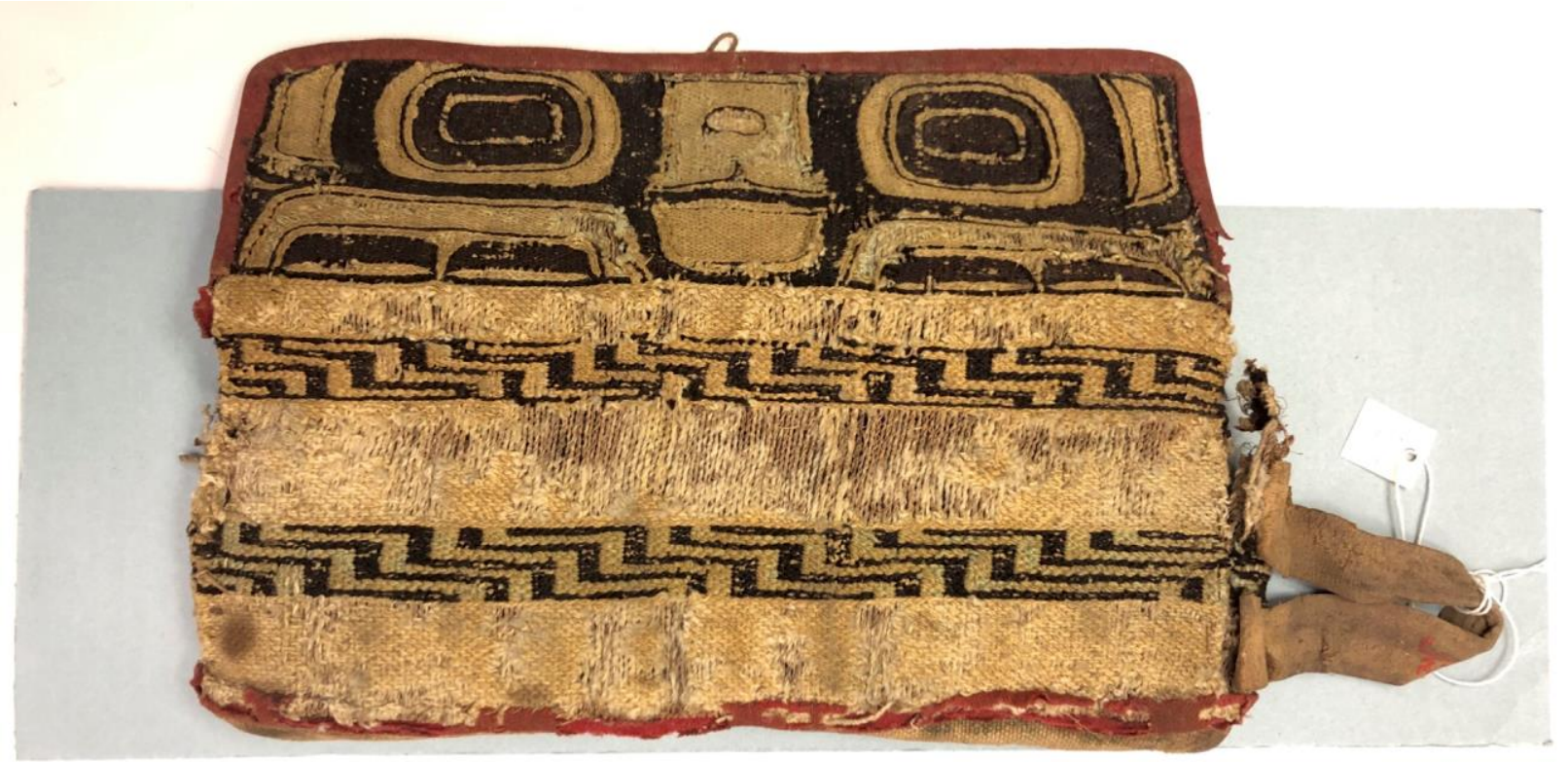

Ammunition case (open, back), artist once known, Chilkat Tlingit. Collected 1882-1887. Cedar bark, mountain-goat wool, metal, trade cloth, hide, glass. $11 \times 4$ 3/4 in. Image: Laura Allen; Courtesy of the Division of Anthropology,

American Museum of Natural History, 19/207.

The separation of Chilkat artist and weaver has long been dogma in Northwest Coast art history. Women are generally regarded as having both designed and woven geometric Raven's Tail patterns. But for Chilkat weaving, the long-prevaling notion was, as anthropologist Erna Gunther put it in 1920, that "there is no opportunity whatever for the women to show their creative ability in this work." 26

However, female-designed geometric patterns remained a small but ongoing component of Chilkat-style weaving - mostly on small objects and on woven tunics - through the late nineteenth century, even after the Raven's Tail style was only a memory. ${ }^{27}$ The maxim that women relinquished their roles as textile designers after Raven's Tail "transitioned" to Chilkat style is further disrupted by this ammunition case. My research supports a growing recognition that nineteenth-century weavers on the Northwest Coast were indeed still showing their "creative ability" for the woven textiles they executed - and that they could choose to do so with specific cultural values and social outcomes in mind..$^{28}$ Tlingit weaver Lily Hope underscored the need for a revision of entrenched beliefs about the validity of so-called "women's art" versus "men's art" on the Northwest Coast. "I don't think Chilkat and Raven's Tail weavers get enough credit for being contemporary in their times," she said. "For weaving with intent." 29

\footnotetext{
${ }^{26}$ Erna Gunther, Design Units on Tlingit Baskets (Sitka: Friends of the Sheldon Jackson Museum, 1990), 5.

${ }^{27}$ In fact, Samuel's book depicts several small objects with both curvilinear and geometric designs on the page where she makes the cited statement, but she did not choose to examine their duality of pattern types.

${ }^{28}$ See Aldona Jonaitis, "The Scientist and the Polymath,” 124-125 and Emily Moore, "Naaxiin Tunics" (paper presented at the Native American Art Studies Association Biennial Meeting, Minneapolis, MN, October 3, 2019).

${ }^{29}$ Hope, interview by author, April 23, 2020.
} 
Tlingit women's designs are quite evident on sleeved tunics, a type of late-nineteenth-century Chilkat weaving that has often been as sidelined as small weavings. ${ }^{30}$ Emily Moore proposes that for some tunics, weavers translated the crest designs on the front from three-dimensional house posts designed and carved by men without using a pattern board. ${ }^{31}$ And the backs of tunics typically consist of large-format geometric designs - women's designs - such as checkerboards, waves, or zigzags, as seen below. Scholars have noted many similarities between the geometric banding on the backs of woven tunics and the quillworking on hide tunics from Athabascansgroups with which the Jilkaat and Jilkoot Tlingit, especially, traded - as well as with Tlingit spruce-root basketry. 32

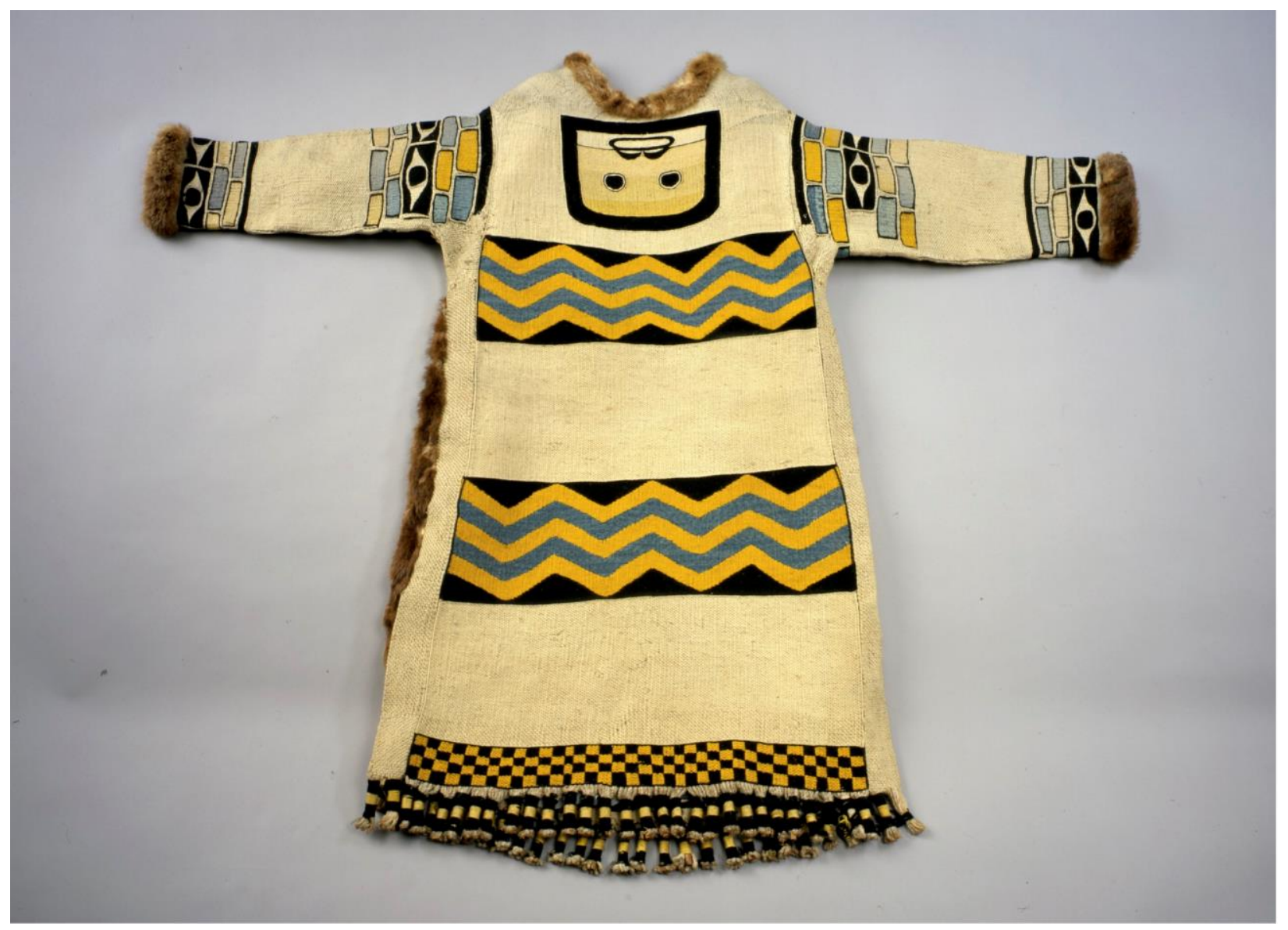

Chilkat tunic (back), Mrs. Benson (Tlingit, active late 19th century). Ca. 1885. Mountain-goat wool, sea otter fur, cedar bark. 34 in $x 29$ 1/2 in. Museum Purchase: Indian Collection Subscription Fund, Rasmussen Collection of Northwest Coast Indian Art. Portland Art Museum, Portland, Oregon, 48.3.548

\footnotetext{
${ }^{30}$ Emily Moore, "Chilkat Tunics: Toward a Reassessment of the Configurative" (paper presented at Sharing Our Knowledge: A Conference of Tsimshian, Haida, and Tlingit Tribes and Clans, Sitka, AK, March 22, 2007).

${ }^{31}$ Moore, "Naaxiin Tunics."

32 Judy Thompson, "Some Curious Dresses of the Natives: A Re-Examination of Some Early Garments from the Alaska Coast," American Indian Art Magazine 16, no. 3 (Summer 1991): 72-75.
} 
The banded stair-step pattern on this ammunition case somewhat resembles the backs of tunics. ${ }^{33}$ However, it is more finely rendered and intricate, closer to the scale and layout of basketry or Raven's Tail work. ${ }^{34}$ That said, I have thus far not seen this particular stair-step pattern on any historic Raven's Tail or "transitional-period" wool weaving. The stair-step is in fact an old Tlingit basketry and quillwork motif. As with many conventionalized designs, its representation is ambiguous. Emmons recorded that it "was believed to have been copied from the profile of the mountain... as it descends to the water in step-like plateaus." ${ }_{35}$ However, Jenny Thlunaut, a naaxein weaver born around 1890, reportedly knew the pattern as the "seasons of the year." 36

Whatever it may represent directly, the motif has other associations that may be relevant to the designer's intent. Emmons noted the pattern's name as shadaa ya.áagi in Tlingit. Shadaa ya.áagi means "weaving for the head." The word refers to a distinctive style of flat, peaked hat worn by Tlingit shamans to fight spirits. ${ }^{37}$ Emmons named the pattern "shaman's hat" in English, which Hotch suggests he did to give it "more notoriety, more flair." 38 This type of hat was also worn by warriors in battle..$^{39}$ Basketry and quillwork versions of this hat, and sometimes versions in imported or locally made fabric, commonly sported the stair-step design, or variants of it, as seen in the image on the next page..$^{40}$ While this pattern is not exclusive to "war bonnets," especially in the late nineteenth century, my research in collections confirms that it is especially linked to them, even when accounting for Emmons' tendency for hyperbole. He noted in 1903 that: "No particular [basketry] design is attached to any particular form, except in the case of the shaman's war-bonnet, on which the step-like character is seldom wanting." ${ }^{41}$ It appears, then, that the geometric pattern selected for this ammunition case was linked to spiritual and physical combat when shamanism was strong and war was ongoing in the mid-nineteenth century. ${ }^{42}$

\footnotetext{
${ }^{33}$ Henrikson, email message to author, March 2, 2020.

${ }^{34}$ Hope, interview by author, April 23, 2020.

${ }^{35}$ George Thornton Emmons, "The Basketry of the Tlingit," Memoirs of the American Museum of Natural History 3, no. 2 (1903): 274.

${ }^{36}$ Hotch, interview by author, April 28, 2020 and email message to author, July 9, 2020.

${ }^{37}$ Emmons, "Basketry," 257. Emmons spelled this word "shar-dar yar-ar-kee," or a variation. He was not trained in linguistics. I use Nora Marks Dauenhauer's transliteration of the term in the Naish-Story orthography. See George Thornton Emmons, The Basketry of the Tlingit and the Chilkat Blanket, with revised appendices by Nora Marks Dauenhauer, Kent Hanson, Mary Clay Muller, Victoria M. O’Connell, (Sitka: Friends of the Sheldon Jackson Museum, 1993), xiv. See also de Laguna, Under Mount Saint Elias, 591.

${ }^{38}$ Hotch, email message to author, July 9, 2020.

39 John R. Swanton, "Social Conditions, Beliefs and Linguistic Relationship of the Tlingit Indians," in Twenty-Sixth Annual Report of the Bureau of American Ethnology, 1904-1905 (Washington, DC: U.S. Bureau of American Ethnology, 1908), 450, https://repository.si.edu/handle/10088/91722. While a shaman would always join a Tlingit war-party, it appears that non-shamanic warriors could wear the hats while fighting.

${ }^{40}$ Emmons, "Basketry," 257, 274; Emmons, Tlingit Indians, 220.

${ }^{41}$ Emmons, "Basketry," 262.

42 Judy Thompson suggests that Athabascan-style porcupine quillwork, and perhaps Tlingit-adapted versions of those quillwork designs in wool, may have been considered to confer spiritual protection. See Thompson, "Some Curious Dresses," 73.
} 


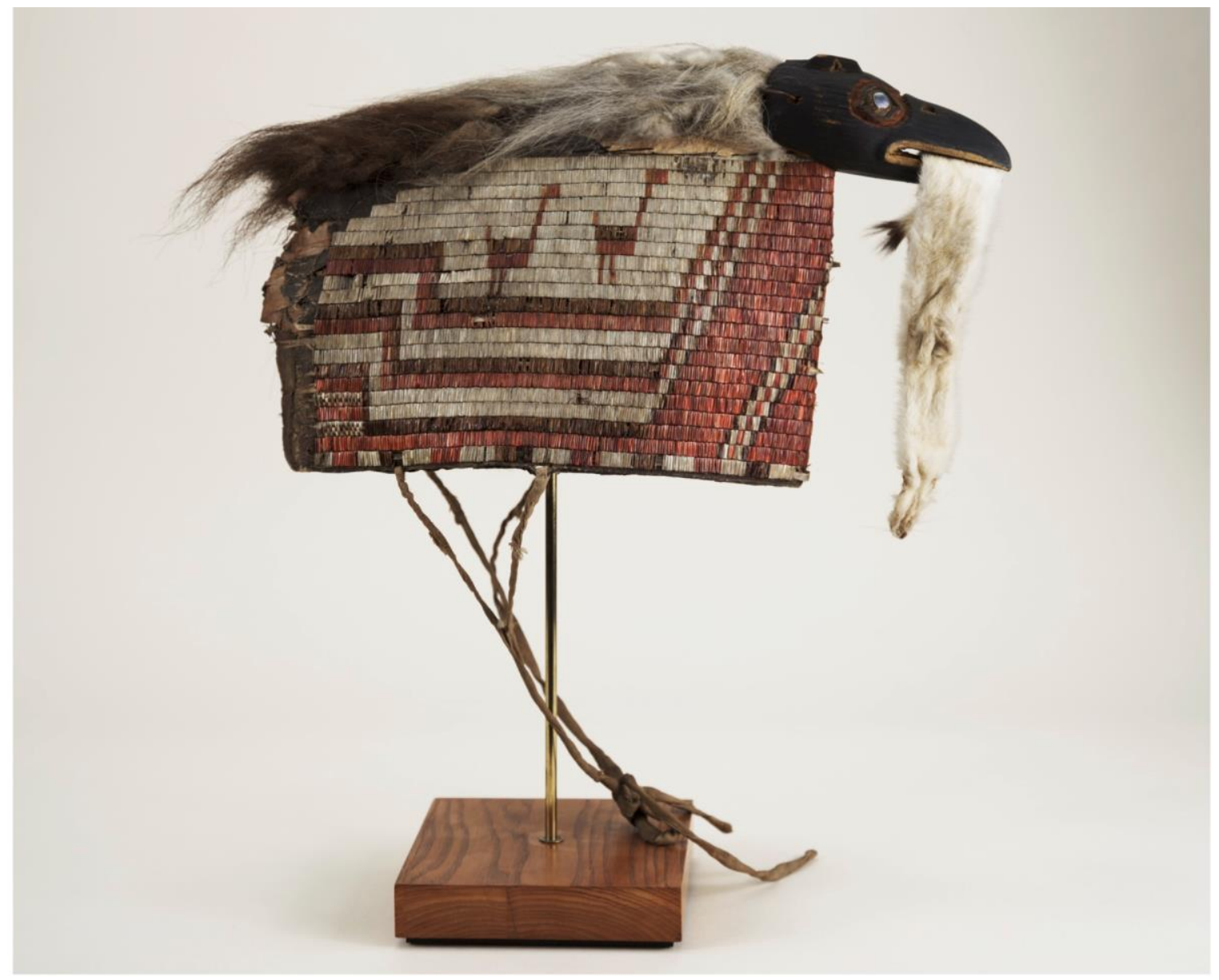

Shadaa ya.áagi pattern on its namesake hat in porcupine quilling, owned by Chilkoot Tlingit. Accessioned 1927. Birch bark, wood, abalone shell, porcupine quill, fur, hide, cotton. $161 / 4 \times 7$ in. Image courtesy of the Penn Museum, object no. NA11758.

\section{$\underline{\text { Interpretations and Adaptations }}$}

What do these possibilities suggest about social transitions related to the woven ammunition case? I speculate that the case was made in the early-to-mid-nineteenth century. My assessment of the pouch's condition, colors, warp and weft counts, and other weaving features-which I cannot detail here- - suggest this dating. ${ }^{43}$

By the mid-nineteenth century, conditions for local Native people were becoming precarious. The fur trade social economy - destabilizing and uneven in its own right - was giving way to increasing colonial settlement, control, and exploitation. In 1867, Russia sold Alaska to the United States without the consent of its Native landowners. The U.S. military began aggressively governing the region while suppressing aboriginal warfare. During the 1880s and 1890s, the U.S. Navy and missionaries worked vigorously to eliminate shamanism through punishment and

\footnotetext{
${ }^{43}$ My research also suggests that the woven case is a Tlingit-made piece and not a Tsimshian one as Katie Pasco has proposed, particularly given its use of a prominent Tlingit pattern. See Pasco, "Tsimshian Connection," 45.
} 
religious conversion. ${ }^{44}$ Colonial governance, wage labor systems, and tourist markets altered Tlingit sociopolitical structures and prestige and subsistence economies. By 1904, the Alaskan government attempted to ban potlatches outright. These cumulative pressures affected the social currencies and visual culture of Native attire.

If this ammunition case was indeed made at the head of this volatile period and was passed down over generations like many treasured objects, it could have exerted useful symbolic power across decades, adapted anew with each successive owner. It is a container for objects to vanquish an enemy. It is marked with a symbol of combat in both spiritual and physical realms. It projects related forms of strength adaptable for changing social circumstances. I suggest that this prestigious case, whether it was for real or symbolic ammunition, could have been appropriate both in the field and as ku.éex' regalia during a period when actual war was giving way to metaphorical war, anticipating the later use of exclusively ceremonial beadwork cartridge belts.

As a "connective object," the case also heralds innovations and expansions for older basketry motifs in the late nineteenth century. For example, Tlingit women rendered shadaa ya.áagi and other basketry designs in beads on the V-shaped yokes of Athabascan-style tunics they made from trade cloth. ${ }^{45}$ They also adapted the pattern for large beaded hair ornaments worn by elite young Tlingit women to display their status and femininity, ${ }^{46}$ an effect bolstered, perhaps, by the mobilization of women's pattern design. By the 1890s, the shadaa ya.áagi pattern became even more widespread on baskets themselves as Tlingit women rapidly increased their production to meet a surge of touristic demand. ${ }^{47}$ "What our ancestors did one hundred years ago may differ from how their ancestors did things two hundred years ago," said Lani Hotch. "I believe that each generation has a right, if not a duty, to influence their culture." ${ }^{48}$

Tlingit artists today continue to use the stair-step pattern, translating it anew in wool, basketry, beadwork, glass, and other media. Hotch herself applied it to a small weaving she made recently, a headband (see next page). She said that the motif has no special significance for her, emphasizing it as the "seasons" pattern. ${ }^{49}$ In some cases, the design has come to represent the Tlingit as a cultural entity. For example, in 1979 Haida weaver Delores Churchill chose it to stand for the Tlingit in a basket that represents the basketry styles of four cultural groups. ${ }^{50}$

\footnotetext{
${ }^{44}$ Emmons, Tlingit Indians, 375, 404; Frederica de Laguna, “George Thornton Emmons as Ethnographer,” in Emmons, Tlingit Indians, xviii.

${ }^{45}$ Smetzer, personal communication, July 9, 2020.

${ }^{46}$ De Laguna, Under Mount Saint Elias, 591; Alyssa Greenberg and Aaron Glass, "Hair Ornament," Objects of Exchange, Bard Graduate Center, accessed June 23, 2020, https://www.bgc.bard.edu/objects-exchange-hairornament.

${ }^{47}$ Emmons, "Basketry," 274; Emmons, Tlingit Indians, 222.

${ }^{48}$ Hotch, email message to author, January 25, 2021.

${ }^{49}$ Hotch, interview by author, April 28, 2020.

${ }^{50}$ See also Teri Rofkar, "A Tribute to Emily." In Native American Voices on Identity, Art, and Culture: Objects of Everlasting Esteem, edited by Lucy Fowler Williams, William Wierzbowski, and Robert W. Preucel (Philadelphia: University of Pennsylvania Museum of Archaeology and Anthropology, 2005), 167.
} 
Nineteenth and early twentieth-century anthropologists like Emmons and Boas, who perceived ancestral cultures as more "authentic," saw these changes as problematic. For example, Emmons thought they signaled cultural degeneration, writing in 1903 that "The old characters are being combined to form attractive although meaningless figures, and so symbolism in design will gradually be lost." ${ }^{51}$ Boas likewise disregarded the substance of women's art: "From the way in which these [patterns] are used we may infer that they have no symbolic significance," he wrote in 1927. ${ }^{52}$ With these erroneous assumptions, both ethnographers failed to see the undercurrents of meaning that can persist in women's art, that old patterns can acquire fresh meanings, and that radically new symbolic designs can and do emerge - all equally valid and wielding social power.

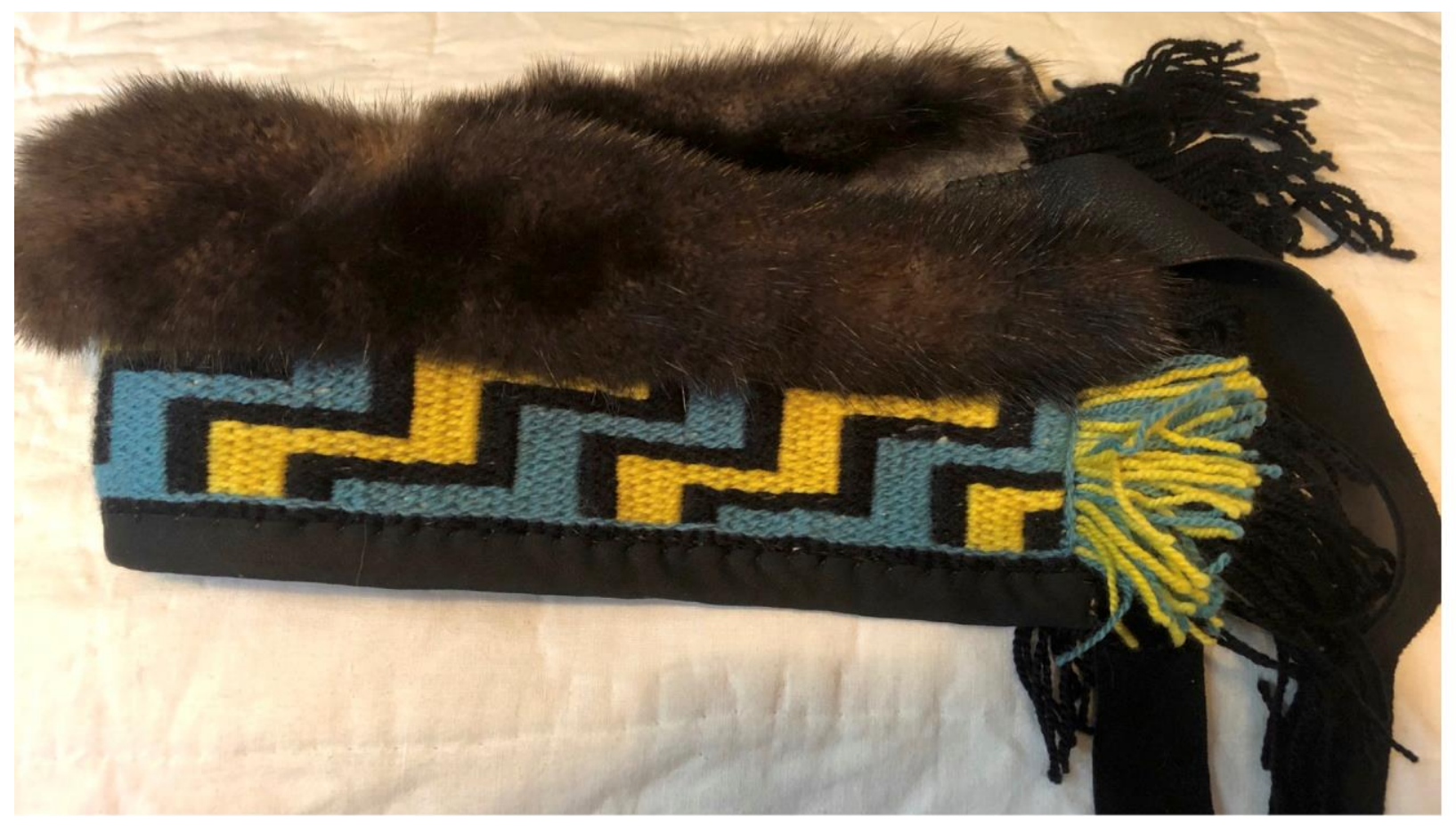

Headband, Lani Hotch, Chilkat Tlingit. 2020. Sheep's wool, sea otter fur, cloth. Image courtesy of Lani Hotch.

In conclusion, I interpret this ammunition case as connecting some shifting tides of artistic meaning and social experience among the nineteenth-century Tlingit. The designer-weaver may have intended to mark warrior or shamanic social symbolism for its owner along with crestbearing ceremonialism, equally valuable in a trade transaction, in armed conflict, or at a potlatch. I argue that in referencing older basketry or quillwork designs, she drew on the Raven's Tail textile tradition in a forward-thinking way. This choice anticipated new, less obvious interpretations of an old pattern as Tlingit material culture and identity began to be more widely exported outside of southeast Alaska.

Like this ammunition case and its interpretations, social transitions are ambiguous, slippery. Sometimes, they are not transformations from one state of being to another at all, but rather

\footnotetext{
51 Emmons, "Basketry," 262.

${ }^{52}$ Franz Boas, Primitive Art (New York: Dover Publications, 1955), 290.
} 
adaptations of cultural norms in response to changing social circumstances. ${ }^{53}$ This might especially apply to the nineteenth-century Tlingit, who resisted many incursions of their culture. The physical space on this ammunition case was an opportunity for creativity with form and social codes during a time-space of great flux. As Hotch put it to me: "Who knows what [the weaver's] intention was? A lot of times, you have a space you want to fill, and the design just comes to you. $" 54$

I thank the staff of the AMNH Division of Anthropology for facilitating my March 2020 research visit. I am grateful to Lani Hotch, Evelyn Vanderhoop, Jisgang Nika Collison, Lily Hope, Steve Henrikson, and Garfield George for discussing this and related objects with me. I am also obliged to Hotch, Aaron Glass, Aldona Jonaitis, and Megan Smetzer for sharing images and research materials and for their helpful comments on draft text. Finally, I thank the Textile Society of America for selecting my paper presentation for a 2020 Founding Presidents Award.

\section{Bibliography}

Boas, Franz. Primitive Art. New York: Dover Publications, 1955.

de Laguna, Frederica. "George Thornton Emmons as Ethnographer.” In Emmons, The Tlingit Indians, xvii-xxv. Anthropological Papers of the American Museum of Natural History 70. Seattle: University of Washington Press, 1991. http://digitallibrary.amnh.org/handle/2246/253.

- Under Mount Saint Elias: The History and Culture of the Yakutat Tlingit. Smithsonian Contributions to Anthropology, vol. 7. Washington: Smithsonian Institution Press, 1972. Emmons, George Thornton. "The Basketry of the Tlingit." Memoirs of the American Museum of Natural History 3, no. 2 (1903): 229-77.

- The Basketry of the Tlingit and the Chilkat Blanket. With revised appendices by Nora Marks Dauenhauer, Kent Hanson, Mary Clay Muller, Victoria M. O’Connell. Sitka: Friends of the Sheldon Jackson Museum, 1993.

- The Tlingit Indians. Edited with additions by Frederica de Laguna and a biography by Jean Low. Anthropological Papers of the American Museum of Natural History 70. Seattle: University of Washington Press, 1991. http://digitallibrary.amnh.org/handle/2246/253.

Glass, Aaron, ed. Objects of Exchange: Social and Material Transformation on the Late Nineteenth-Century Northwest Coast. New York: Bard Graduate Center, 2011.

Greenberg, Alyssa, and Aaron Glass. "Hair Ornament." Objects of Exchange. Accessed June 23, 2020. https://www.bgc.bard.edu/objects-exchange-hair-ornament.

Grinëv, A. V. The Tlingit Indians in Russian America, 1741-1867. Translated by Richard L. Bland and Katerina G. Solovjova. Lincoln: University of Nebraska Press, 2005. https://search-ebscohost-com.ezproxy.cul.columbia.edu/login.aspx?direct=true\&db $=\mathrm{e} 025 \mathrm{xna} \& \mathrm{AN}=135774 \&$ site $=$ ehost-live $\&$ scope $=$ site

Gunther, Erna. Design Units on Tlingit Baskets. Sitka: Friends of the Sheldon Jackson Museum, 1990.

Henrikson, Steve. "Yéil Koowú: The Reemergence of Ravenstail Weaving On the Northwest Coast.” American Indian Art Magazine 18, no. 1 (Winter 1992): 58-67.

\footnotetext{
${ }^{53}$ Glass, Objects of Exchange, 17-18.

${ }^{54}$ Hotch, interview by author, April 28, 2020.
} 
Holm, Bill. "A Wooling Mantle Neatly Wrought: the Early Historic Record of Northwest Coast Pattern-Twined Textiles.” American Indian Art Magazine 8, no. 1 (Winter 1982): 34-47.

Jonaitis, Aldona, ed. A Wealth of Thought: Franz Boas on Native American Art. Seattle:

University of Washington Press, 1995.

— . "The Scientist and the Polymath: Tlingit Weavers Teri Rofkar and Clarissa Rizal." In Hearts of Our People: Native Women Artists, edited by Jill Ahlberg Yohe and Teri

Greeves. Minneapolis: Minneapolis Institute of Art, 2019.

Kan, Sergei. "Events and Nonevents on the Tlingit/Russian/American Colonial Frontier, 18021879." In New Perspectives on Native North America: Cultures, Histories, and

Representations, edited by Sergei Kan, Pauline Turner Strong, and Raymond Fogelson, 310-26. Lincoln: University of Nebraska Press, 2006.

Kissell, Mary Lois. "The Early Geometric Patterned Chilkat." American Anthropologist 30, no. 1 (1928): 116-20.

Klassen, Rebecca. "Ammunition Case.” In Objects of Exchange: Social and Material

Transformation on the Late Nineteenth-Century Northwest Coast, edited by Aaron Glass, 131-33. New York: Bard Graduate Center, 2011.

Moore, Emily. "Chilkat Tunics: Toward a Reassessment of the Configurative." Paper presented at Sharing Our Knowledge: A Conference of Tsimshian, Haida, and Tlingit Tribes and Clans, Sitka, AK, March 2007.

_. "Naaxiin Tunics." Paper presented at the Native American Art Studies Association Biennial Meeting, Minneapolis, MN, October 2019.

Pasco, Katie. "The Tsimshian Connection in Weaving the Painted Formline." American Indian Art Magazine 22, no. 2 (1997): 44-51.

Rofkar, Teri. "A Tribute to Emily." In Native American Voices on Identity, Art, and Culture:

Objects of Everlasting Esteem, edited by Lucy Fowler Williams, William Wierzbowski,

and Robert W. Preucel. Philadelphia: University of Pennsylvania Museum of Archaeology and Anthropology, 2005.

Samuel, Cheryl. The Chilkat Dancing Blanket. Norman: University of Oklahoma Press, 1982. . The Raven's Tail. Vancouver, BC: UBC Press, 1987.

Smetzer, Megan. "Assimilation or Resistance? The Production and Consumption of Tlingit Beadwork." PhD diss., University of British Columbia, 2007.

Swanton, John R. "Contributions to the Ethnology of the Haida." In Memoirs of the American Museum of Natural History, Vol. 8. Part 1. New York: American Museum of Natural History, 1905. http://digitallibrary.amnh.org/handle/2246/5742.

. "Social Conditions, Beliefs and Linguistic Relationship of the Tlingit Indians." In

Twenty-Sixth Annual Report of the Bureau of American Ethnology, 1904-1905, 391-485.

Washington, DC: U.S. Bureau of American Ethnology, 1908.

https://repository.si.edu/handle/10088/91722.

Thomas, Nicholas. Entangled Objects: Exchange, Material Culture, and Colonialism in the

Pacific. Cambridge, MA: Harvard University Press, 1991.

Thompson, Judy. "Some Curious Dresses of the Natives: A Re-Examination of Some Early Garments from the Alaska Coast." American Indian Art Magazine 16, no. 3 (Summer 1991): 66-75.

Twitchell, X'unei Lance, ed. Tlingit Dictionary. Juneau: University of Alaska Southeast/Goldbelt Heritage Foundation, 2016. 